\author{
Halil Tunca*, Ferda Esin Gulel**
}

\title{
Youth unemployment and crime: an empirical investigation for Turkey
}

\section{Introduction}

The crime economy has lately become a popular field of research because of the regular increases in crime rates. Questions such as what the main socioeconomic factors affecting crime rates are and why crime rates are higher in some regions and at certain times, are the main issues for which not only economists but also researchers from other disciplines seek answers.

Economists' interest in crime analysis goes back to Becker's (Becker, 1968) model. According to this model, criminal behaviour is governed by an evaluation of benefits and costs of crimes. If the benefit from the crime is higher than the cost to be faced, the individual will be willing to commit the crime. Concerning this model, the probability of being caught and punished of individuals are the main factors that directly affect the tendency to crime. As an increment in these possibilities increases the cost of illegal activity, the crime tendency of the individuals will decrease. Later, Becker's model was extended by Ehrlich (Ehrlich, 1973) with the addition of the time allocation problem. According to Ehrlich's crime model, individuals have to decide how to distribute their time between legal and criminal activities. Based on this model, it can be said that legal and criminal activities are the substitute activities, and individuals' decisions are determined by opportunity costs. If the individual's income from the legal activity is low, the time allocated to illegal activity will be increased because the opportunity costs that an individual gives up is low. It is possible that Ehrlich model can be tested by empirical studies. Therefore a vast empirical literature has been emerged up to date. In these studies, the most commonly

\footnotetext{
* Pamukkale University, Economics and Administration Faculty, Economics Department, e-mail htunca@pau.edu.tr.

** Pamukkale University, Economics and Administration Faculty, Econometrics Department, e-mail: fegulel@pau.edu.tr
} 
used variables are income, income distribution, unemployment, educational levels, and migration, etc.

One of the factors studied within the crime phenomenon is migration. The main reason for migration is unemployment and poverty. The problem of adaptation to the city with migration increases the likelihood of people turning towards crime (TESEV, 2005). Migration is a case that affects almost every structure of society as well as the psychology of the individual (Güvenç, 1996).

The main purpose of this study is to determine the relationship between youth unemployment and crime rates by migration-receiving of regions. For this purpose, aggregated crime rates, as well as non-aggregated crime rates (property crime, theft, and violent crime), were used. Also, the youth unemployment rate has been subdivided by gender differences and educational levels. Thus, the effects of gender differences on crime rates can be tested separately. Additonally, the effectiveness of the education system in Turkey can also be investigated, in terms of what it does to keep individuals away from illegal activities. We prefer to use spatial econometrics models in this study because of the unemployment rate and crime rate show regional cluster pattern. A spatial weight matrix is created by migration-receiving of regions.

The rest of the paper is organized as follows. The next section briefly summarizes how crime rates in Turkey develop over the years. In section 3, the empirical literature is discussed. The data are introduced in section 4, and spatial econometrics model used in this paper is summarized. After this section, the empirical results obtained by our spatial model are explained. Finally, the last section concludes the paper.

\section{Change in crime rates over time in Turkey}

Crime rate shows a steady increase in Turkey as well as in the whole world. As seen in Figure 1, the total crime rate was 277.3 in 2008 reached 690.9 in 2017.

This situation indicates that the total number of criminals increased by an average of $12.2 \%$ per year in the $2008-2017$ period. The total crime rate per 10000 individuals, which depict a relatively stable structure in the 2008-2011 period, showed a significantly increasing trend until 2015 after decreasing to a minimum level in 2011 . The total crime rate increased by $9 \%$ and $10 \%$ respectively in the last two years, after a fall of approximately $4.5 \%$ in 2015 .

Table 1 shows the descriptive statistics of total crime rates concerning NUTS2 (26 sub-regions of Turkey) classification ${ }^{1}$, while Figure 2 illustrates the spatial distribution of total crime.

\footnotetext{
1 This classification is given on appendix.
} 
Youth unemployment and crime: an empirical investigation for Turkey

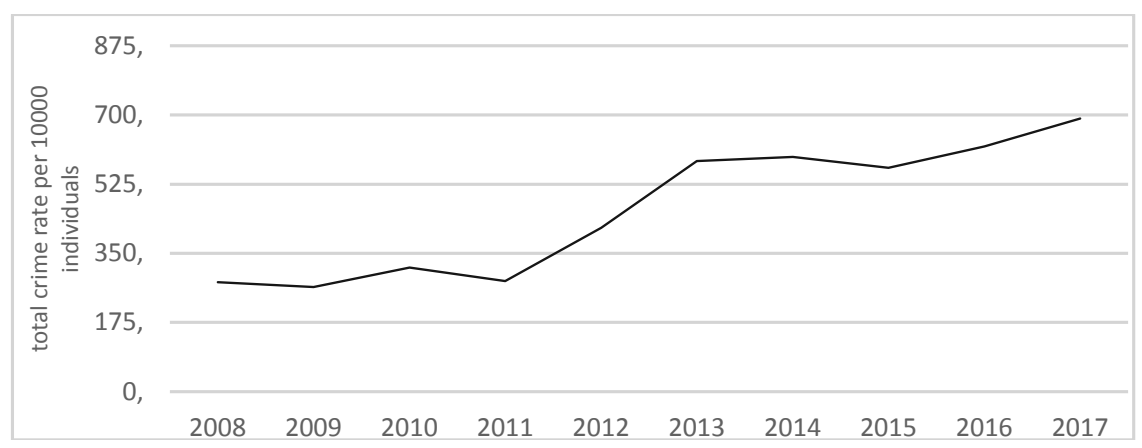

Figure 1. Change in total crime over time: Turkey

Source: Turkish Statistical Institute

Table 1

Descriptive statistics of total crime rate: 2008-2017

\begin{tabular}{|c|c|c|c|}
\hline Region & Max & Average & Std Deviation \\
\hline TR32 & 38.70883 & 27.87632 & 8.105167 \\
\hline TR61 & 41.26014 & 27.50691 & 8.736113 \\
\hline TR31 & 40.03573 & 26.78062 & 9.813951 \\
\hline TR22 & 33.6495 & 25.85908 & 6.89334 \\
\hline TR62 & 40.39491 & 23.9313 & 10.83657 \\
\hline TR33 & 31.367 & 22.84178 & 6.622252 \\
\hline TR21 & 30.7911 & 21.89715 & 6.346248 \\
\hline TR41 & 29.33979 & 18.78544 & 6.65831 \\
\hline TR52 & 29.04211 & 18.31287 & 7.856127 \\
\hline TR71 & 26.58296 & 18.07949 & 7.18804 \\
\hline TR83 & 25.51033 & 17.95031 & 6.612537 \\
\hline TR81 & 25.29 & 17.74285 & 6.157427 \\
\hline TR72 & 28.09648 & 17.31333 & 7.407439 \\
\hline TR42 & 25.14531 & 16.77452 & 5.651034 \\
\hline TR82 & 22.08004 & 16.1766 & 6.116586 \\
\hline TRC1 & 24.52746 & 16.05426 & 5.618019 \\
\hline TRA1 & 21.87608 & 15.40074 & 5.793147 \\
\hline
\end{tabular}


Table 1 cont.

\begin{tabular}{|c|c|c|c|}
\hline Region & Max & Average & Std Deviation \\
\hline TR63 & 21.86609 & 14.76649 & 6.394683 \\
\hline TRB1 & 21.42279 & 14.50654 & 5.816536 \\
\hline TRA2 & 21.78686 & 13.88148 & 6.107592 \\
\hline TR51 & 21.53892 & 13.68774 & 4.535747 \\
\hline TR10 & 22.27792 & 13.35211 & 4.658629 \\
\hline TR90 & 21.04441 & 12.98516 & 6.537087 \\
\hline TRC2 & 18.31154 & 10.85225 & 4.784498 \\
\hline TRB2 & 17.44751 & 9.697744 & 4.836632 \\
\hline TRC3 & 14.80248 & 7.550883 & 4.131512 \\
\hline
\end{tabular}

Source: Turkish Statistical Institute

According to Table 1, the highest crime rates are observed in TR32 (Aydin sub-region), TR61 (Adana sub-region) and TR31 (Izmir sub-region). On the other hand, the lowest crime rates are observed in TRC2 (Şanlıurfa sub-region), TRB2 (Van sub-region) and TRC3 (Mardin sub-region). Observed high standard deviation values in all regions indicate that high variability in crime rates in Turkey. According to the above information, in Turkey, regions where relatively developed have high crime rates, while it is seen that relatively less developed regions have a low crime rate. Figure 2 illustrates this information.

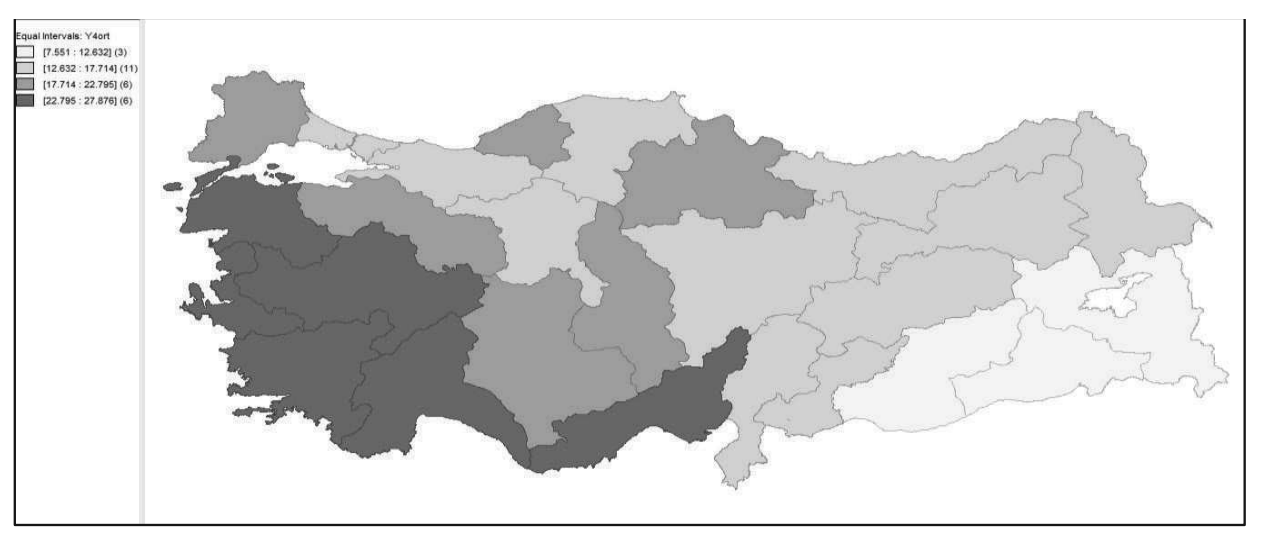

Figure 2. Spatial map of total crime rate distribution

Source: own calculation 
The dark colour areas on the map show high crime rates, while in the regions whose colour is getting lighter crime rates decrease. The west part of Turkey has relatively better developed regions than the rest of the country. So this map clearly indicates that there is a positive relationship between crime rate and developing levels. Besides this, we can certainly say by this map that crime rates have a distinct spatial pattern.

\section{Survey of empirical literature}

As mentioned before, after Becker and Ehrlich's paper, a vast empirical literature occurred about crime economy. Economists' have preferred to research crimes against property rather than other types of crimes, so the relationship between crimes against property and socio-economic variables were more examined. Empirical studies in the literature may be differentiated by the employed model, investigated period, sample size, and used variables. Variables such as income, unemployment, poverty, inflation, wage, economic crisis, and poor income distribution are more employed than the other in the empirical literature. But there is no common consensus about how these variables affect the crime rates.

Altındağ (Altındağ, 2012) analyzed the relationship between crime and unemployment for the period 1995-2003 in 33 European countries. Eight different crime definitions such as homicide rate, assault rate, rape rate, robbery rate, property crime rate, etc. were used as dependent variables in the study. Estimated results showed that there was a positive and significant relationship between unemployment and property crime, larceny, and vehicle theft. Moreover, the unemployment rate was subdivided according to education levels, and it was seen that the effects of low education levels on crime are more significant.

In Lombardo and Falcone (2011) 103 Italian provinces were sub-divided into seven different groups by using cluster analysis. Their results indicated that the highest crime rates are seen in regions where divorce rate, youth unemployment and women's employment are high. Contrary to expectations, it was found that crime rates do not have a spatial pattern.

Saridakis and Spengler (Saridakis and Spengler, 2012) estimated panel models for Greece using regional data for the 1991-1998 period. In the model, three different crimes against property and three different violent crime were used as the dependent variable, and rate of caught, unemployment and the lagged crime rate were used as explanatory variables. The results indicated that there was a significant and expected relationship between a crime against property and the explanatory variable, while there was not any relationship with respect to violent crime. 
Cerro and Meloni (Cerro and Meloni, 2000) investigated socio-economic determinants of the crime rate in Argentina for the period 1990-1999. They found a significant deterrence effect. Furthermore, the unemployment rate and income inequality were found to have a positive and significant effect on the crime rate.

Entorf and Spengler (Entorf and Spengler, 2000) employed panel data for the German states to explore criminal behavior. They used eight different crime variables like robbery, theft, fraud, murder, rape, etc. Their result indicated a strong deterrence effect. Additionally, they found that "being young," and GDP have a positive effect on crime. But these effects were more pronounced with regard to all types of property crime. The effect of unemployment was found as small, often insignificant of ambiguous sign in models. But, being young and unemployed, increases committing a crime and this variable had a positive effect on all types of crime.

Jennings et al. (Jennings et al., 2012) employed time series analysis to determine how to effect socio-economic variables to the property crime rate in England and Wales for the 1961-2006 period. For these purposes, they used unemployment, income inequality, welfare spending, and incarceration variables and found that expected sign and a significant effect on property crime rate except for income inequality.

Ajaegbu (Ajaegbu, 2012), in another study using descriptive analysis, stated that youth unemployment in Nigeria is the main cause of violent crime. Consequently, policies implemented to eliminate youth unemployment will also lead to a reduction in violent crimes. Adebayo (Adebayo, 2013), another study used descriptive analysis, showed the existence of a positive relationship between youth unemployment and crime rates in Nigeria, and stated that the biggest obstacle to economic development is the young unemployed who are involved in crime.

Narayan and Smyth (Narayan and Smyth, 2004) applied the co-integration analysis to explore the relationship between 7 different types of property crime and violent crime, male youth unemployment and male income in Australia from 1964 to 2001. It was found that fraud, homicide and motor vehicle theft are co-integrated with male unemployment and income. However, there was no relationship between other crime types, unemployment and income.

Özer and Topal (Özer and Topal, 2017) estimated a panel data model by using Turkey's NUTS2 regions' data for the 2004-2016 period. According to the estimation results, there was a statistically significant and positive relationship between youth unemployment and crime, migration, suicide and divorce.

Fougere et al. (Fougere et al., 2009) investigated the impact of unemployment on property crimes and violent crimes in France for the period 1990-2000. Estimation results showed a positive relationship between unemployment and crime. Also, the increase in youth unemployment stimulated the increase in crime. It is emphasized that to struggle against crime effectively; firstly, it must be fought with youth unemployment. 
Carmichael and Ward (Carmichael and Ward, 2000) tried to explore the relationship between unemployment and crime in England and Wales from 1985 to 1995. Different types of crime rates were used in the study. Empirical results of the study indicated that there is a positive relationship between burglary and male unemployment regardless of age. However, they found that while youth unemployment is positively related to violent crime and robbery, there was no evidence of a relationship between adult unemployment and these crimes. However, results confirmed a positive connection between adult unemployment and theft.

Grönqvist (Grönqvist, 2011) investigated the link between youth unemployment and different types of crime in Sweden. The results revealed that youth unemployment had a positive effect on crime, and the strongest effect was observed in theft. Besides that, the longer the period of unemployment, the greater the positive impact on crime. Also, the lagged crime variable was found to be significant; in other words, crime rates tended to reinforce themselves.

Filiztekin (Filiztekin, 2013) examined the NUTS 2 regions in Turkey by six different types of crime as the dependent variable, while the unemployment and wages were used as independent variables. Empirical results showed that a positive relationship between youth unemployment and all crime type except sex crimes. But results indicated that there was a negative relationship between wage and all crime except sex crimes and financial crimes.

Lauridsen et al. (Lauridsen et al., 2014) employed a spatial panel model by using data obtained sub-regional level (NUTS2) in Turkey for the 2008-2010 period. The empirical results obtained from the model can be summarized as follows; to commit criminal activity in Turkey was negatively related to deterrence. Urbanization, young people population and unemployment rates were positively related to a crime. Although educational attainment was also positively related to crime, this effect seemed to be very small. Finally, they found strong positive spatial spillover effects. However, this spillover was not clear, taking into account the endogenous relationship between crime and risk of deterrence.

Pazarlığlu and Turgutlu (Pazarlığlu and Turgutlu, 2007), explored the relationship between 10 different crime types, unemployment and gross domestic product by using the co-integration analysis for 1968-2004 period. Their results showed that some crime types were positively related to income in the long term in Turkey, but no relationship was detected between unemployment and crime.

\section{Dataset and Method}

\subsection{Dataset}

The dataset used in this study is gathered from Turkey Statistical Institute (TURKSTAT) database. The dependent and independent variables included in 
the model estimates are listed in Table 2. Data on these variables was obtained by 26 sub-regions of Turkey between the years $2008-2017$.

Table 2

The dependent and independent variables in the models

\begin{tabular}{|c|c|c|c|c|}
\hline \multicolumn{2}{|c|}{ Variable } & Definition & Source & Expected \\
\hline \multirow{4}{*}{ 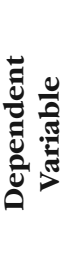 } & Total & Total number of convicted prisoners & TURKSTAT & \\
\hline & Theft & Total number of convicted prisoners for theft & TURKSTAT & \\
\hline & Cap & $\begin{array}{l}\text { Total number of convicted prisoners for } \\
\text { a crime against property }\end{array}$ & TURKSTAT & \\
\hline & Violent & $\begin{array}{l}\text { Total number of convicted prisoners for } \\
\text { violent crimes }\end{array}$ & TURKSTAT & \\
\hline \multirow{8}{*}{ 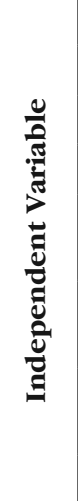 } & Youth & Youth unemployment rate & TURKSTAT & $(+)$ \\
\hline & Adult & Adult unemployment rate & TURKSTAT & $(+)$ \\
\hline & Male & The youth unemployment rate, male & TURKSTAT & $(+)$ \\
\hline & Female & The youth unemployment rate, female & TURKSTAT & $(+)$ \\
\hline & $\begin{array}{l}\text { Under } \\
\text { High }\end{array}$ & $\begin{array}{l}\text { The youth unemployment rate, underhigh } \\
\text { school education level }\end{array}$ & TURKSTAT & $(+)$ \\
\hline & $\begin{array}{l}\text { Above } \\
\text { High }\end{array}$ & $\begin{array}{l}\text { The youth unemployment rate, abovehigh } \\
\text { school education level }\end{array}$ & TURKSTAT & $(+)$ \\
\hline & Higher & $\begin{array}{l}\text { The youth unemployment rate, higher } \\
\text { educational level }\end{array}$ & TURKSTAT & $(+)$ \\
\hline & GDP & Gross domestic product per capita (TL) & TURKSTAT & $(+),(-)$ \\
\hline
\end{tabular}

In Table 2, the definitions of each variable are given. To be more specific, some definitions will be expanded.

The third dependent variable, cap consists of the crimes such as fraud, forgery, debit, bribery, smuggling, damage to property, opposition to bankruptcy and enforcement law. The fourth dependent variable, violent, includes crimes such as homicide, injury, sex crimes, deprivation of liberty, insult, robbery, threat, other crimes with knives and firearms.

Youth unemployment is defined as comprising young people of age is between 15-24. However, adult unemployment is descriptive of the people who are 25 years and older.

The youth unemployment rate by education level cannot be obtained from TURKSTAT for the whole period. Thus, the model that includes under high, above high, and higher variable is estimated in the 2008-2013 period. 
Finally, the total number of convicted prisoners are used as independent variables. When the variables included were per person instead of total numbers, we obtained the same results.

\subsection{Empirical model}

Spatial dependence can be expressed in general in Tobler's (Tobler, 1979) first law: "everything is related to everything else, but near things are more related than distant things." Spatial dependence can occur between dependent variables or error terms. In the spatial lag model, the dependent variable in a region is associated with the dependent variable in neighbouring regions, whereas in the spatial error model, this relationship is seen in the error term. In the first one, the spatial effect is added to the model as an independent variable. In the last one, this effect is included in the error term.

Spatial-effect model estimates can also be made in the panel dataset consisting of time series observations of spatial units. Panel data models are described as the fixed and random effect models according to unobservable effects. If the unobservable effects are included in the constant term in the model, the model is defined as "fixed effect model." However, if the unobservable effects are taken in the error term, the model is called as "random effect model." In this case, it should be decided whether the model has a fixed or random effect as well as a spatial lag or error effect.

The spatial lag model is formulated for the fixed effect panel data model as seen in the following example.

$$
\begin{gathered}
Y_{i t}=\rho W Y_{i t}+X_{i t} \beta+\mu_{i}+\varepsilon_{i t} \\
E\left(\varepsilon_{i t}\right)=0, \quad E\left(\varepsilon_{i t} \varepsilon_{i t}^{\prime}\right)=\sigma^{2} I_{N}
\end{gathered}
$$

Also, the spatial error model is written for the fixed effect model as follows:

$$
\begin{gathered}
Y_{i t}=X_{i t} \beta+\mu_{i}+\phi_{i t} \\
\phi_{i t}=\lambda W \phi_{i t}+\varepsilon_{i t} \\
E\left(\varepsilon_{i t}\right)=0, \quad E\left(\varepsilon_{i t} \varepsilon_{i t}^{\prime}\right)=\sigma^{2} I_{N}
\end{gathered}
$$


Similarly, we can write spatial lag and spatial error models for random effect panel model as formulated in 3 and 4 below.

$$
\begin{gathered}
Y_{i t}=\rho W Y_{i t}+X_{i t} \beta+\varepsilon_{i t} \\
\varepsilon_{i t}=\alpha+\mu_{i t} \\
Y_{i t}=X_{i t} \beta+\varepsilon_{i t} \\
\varepsilon_{i t}=\alpha+B^{-1} u_{i t}, \quad B=I_{N}-\lambda W
\end{gathered}
$$

Where $Y_{i t}$; dependent (crime) variable vector, $X_{i t}$; independent (youth and adult unemployment and GDP) variables matrix and $\varepsilon_{t}$; random disturbance term, $W$; spatial weight matrix, $\rho$; spatial lag term, $\lambda$; spatial error term. $W Y_{i t}$ refers to spatial lagged crime levels obtained by multiplying the regional crime levels with a spatial weight matrix.

In the spatial lag models ( 1 and 3$) \rho$ can be interpreted the existence of spatial interaction, and in our models, positive and significant $\rho$ can be commented as a positive migration effect. The spatial effect in the spatial lag models implies that change in crime level of given sub-region depends on the crime level of the contiguity sub-regions. On the other hand, spatial error models can also be detected existence spatial interactions by $\lambda$ spatial term, but it fails to identify the possible source of spatial effect. This implies that spatial interaction can occur through by variables which are not represented in the model.

Estimation of spatial models with OLS will lead to inconsistent and biased results because the basic assumptions of the OLS estimation process do not apply to spatial models. Therefore, many different models have been proposed by Anselin (Anselin, 1988), Elhorst (Elhorst, 2003) and Baltagi (Baltagi, 2005) to reach consistent predictors as a result of model estimation. In this study, spatial lag models will be estimated using Maximum Likelihood, and spatial error models will be estimated using Generalized Least Squares models.

The existence of spatial effect is determined by the Lagrange Multiplier (LM) test (Anselin, 1988; Bera and Yoon, 1993; Anselin et al., 1996; Anselin et al., 2006). In the determination of spatial lag and error models, respectively, $H_{0}: \rho=0$ (under the assumption of $\lambda=0$ ), $H_{0}: \lambda=0$ (under the assumption of $\rho=0$ ) are tested. On the other hand, whether the model has a fixed or random effect is determined by the Hausman test (Hausman, 1978). In this case, $H_{0}: E\left(u_{i t} / X_{i t}\right)=0$ is tested.

The structure of the weight matrix in the spatial models has great importance for meaningful estimation. The weight matrix was constructed using the migration dataset obtained from the Turkish Statistical Institute to define the spatial effect, which reflects the migration effect in our models. Since the weight matrix always 
Table 3

Estimation results with spatial weight matrix according to the migration of regions

\begin{tabular}{|c|c|c|c|c|c|c|c|c|c|c|c|c|}
\hline & \multicolumn{3}{|c|}{ Theft } & \multicolumn{3}{|c|}{ Cap } & \multicolumn{3}{|c|}{ Violent } & \multicolumn{3}{|c|}{ Total } \\
\hline & Model1 & Model2 & Model3 & Model4 & Model5 & Model6 & Model7 & Model8 & Mode19 & Model10 & Model11 & Model12 \\
\hline intercept & $\begin{array}{c}-778.931 \\
(0.000)\end{array}$ & & $\begin{array}{c}-555.624 \\
(0.000)\end{array}$ & $\begin{array}{l}50.772 \\
(0.930)\end{array}$ & $\begin{array}{l}35.288 \\
(0.949)\end{array}$ & $\begin{array}{c}163.568 \\
(0.746)\end{array}$ & $\begin{array}{c}-1236.2 \\
(0.003)\end{array}$ & $\begin{array}{c}-1286.2 \\
(0.002)\end{array}$ & $\begin{array}{c}-717.198 \\
(0.138)\end{array}$ & $\begin{array}{c}-371.525 \\
(0.591)\end{array}$ & $\begin{array}{c}-465.500 \\
(0.518)\end{array}$ & \\
\hline youth & $\begin{array}{c}-22.424 * * \\
(0.017)\end{array}$ & & & $\begin{array}{l}-6.215 \\
(0.632)\end{array}$ & & & $\begin{array}{c}7.962 \\
(0.616)\end{array}$ & & & $\begin{array}{c}-39.140 \\
(0.332)\end{array}$ & & \\
\hline male & & $\begin{array}{l}15.564^{*} \\
(0.061)\end{array}$ & & & $\begin{array}{l}-6.269 \\
(0.581)\end{array}$ & & & $\begin{array}{l}17.358 \\
(0.207)\end{array}$ & & & $\begin{array}{c}-17.389 \\
(0.634)\end{array}$ & \\
\hline female & & $\begin{array}{c}-13.656^{* *} \\
(0.016)\end{array}$ & & & $\begin{array}{c}3.594 \\
(0.637)\end{array}$ & & & $\begin{array}{l}-9.182 \\
(0.309)\end{array}$ & & & $\begin{array}{l}-9.676 \\
(0.681)\end{array}$ & \\
\hline gdp & $\begin{array}{l}0.094^{*} \\
(0.000)\end{array}$ & $\begin{array}{c}0.079 * * * \\
(0.000)\end{array}$ & $\begin{array}{c}0.057 * * * \\
(0.000)\end{array}$ & $\begin{array}{c}0.023 * * * \\
(0.005)\end{array}$ & $\begin{array}{c}0.024 * * * * \\
(0.004)\end{array}$ & $\begin{array}{c}0.048 * * * \\
(0.005)\end{array}$ & $\begin{array}{c}0.145 * * * \\
(0.000)\end{array}$ & $\begin{array}{c}0.148 * * * * \\
(0.000)\end{array}$ & $\begin{array}{c}0.118 * * * \\
(0.000)\end{array}$ & $\begin{array}{c}0.421 * * * \\
(0.000)\end{array}$ & $\begin{array}{c}0.418 * * * \\
(0.000)\end{array}$ & $\begin{array}{c}0.294 * * * \\
(0.000)\end{array}$ \\
\hline adult & $\begin{array}{c}49.432 * * * \\
(0.004)\end{array}$ & $\begin{array}{c}4.718 \\
(0.798)\end{array}$ & $\begin{array}{l}24.645^{*} \\
(0.052)\end{array}$ & $\begin{array}{l}32.670 \\
(0.175)\end{array}$ & $\begin{array}{l}26.996 \\
(0.258)\end{array}$ & $\begin{array}{l}21.112 \\
(0.574)\end{array}$ & $\begin{array}{l}-0.473 \\
(0.987)\end{array}$ & $\begin{array}{c}0.360 \\
(0.989)\end{array}$ & $\begin{array}{l}4.718 \\
(0.858)\end{array}$ & $\begin{array}{l}81.148 \\
(0.281)\end{array}$ & $\begin{array}{l}61.279 \\
(0.407)\end{array}$ & $\begin{array}{c}-101.269^{*} \\
(0.053)\end{array}$ \\
\hline underhigh & & & $\begin{array}{l}-5.064 \\
(0.432)\end{array}$ & & & $\begin{array}{c}4.794 \\
(0.791)\end{array}$ & & & $\begin{array}{l}-3.784 \\
(0.775)\end{array}$ & & & $\begin{array}{l}42.891^{*} \\
(0.067)\end{array}$ \\
\hline abovehigh & & & $\begin{array}{l}-2.616 \\
(0.512)\end{array}$ & & & $\begin{array}{l}-6.127 \\
(0.584)\end{array}$ & & & $\begin{array}{c}0.059 \\
(0.994)\end{array}$ & & & $\begin{array}{l}9.679 \\
(0.507)\end{array}$ \\
\hline higher & & & $\begin{array}{c}1.019 \\
(0.628)\end{array}$ & & & $\begin{array}{l}-0.828 \\
(0.889)\end{array}$ & & & $\begin{array}{c}6.191 \\
(0.149)\end{array}$ & & & $\begin{array}{c}8.175 \\
(0.289)\end{array}$ \\
\hline$\rho($ error $) / \lambda$ (lag) & -0.340 & & 0.648 & 0.716 & 0.711 & 0.596 & 0.621 & 0.623 & 0.804 & -0.424 & -0.409 & 0.715 \\
\hline spatial effect & Lag & None & Error & Error & Error & Error & Error & Error & Error & Lag & Lag & Error \\
\hline LM test & 5.469 & & 21.989 & 91.752 & 98.4469 & 36.632 & 43.2453 & 42.704 & 72.961 & 16.703 & 15.733 & 6.039 \\
\hline p-value & 0.019 & & 0.000 & 0.000 & 0.000 & 0.000 & 0.000 & 0.000 & 0.000 & 0.000 & 0.000 & 0.014 \\
\hline model effect & Random & Fixed & Random & Random & Random & Random & Random & Random & Random & Random & Random & Fixed \\
\hline Hausmann test & 42.111 & 8.6528 & 104.89 & 9.968 & 13.102 & 583.54 & 97.982 & 618.99 & 112.57 & 42.111 & 11.862 & 3.923 \\
\hline p-value & 0.000 & 0.07039 & 0.000 & 0.019 & 0.011 & 0.000 & 0.000 & 0.000 & 0.000 & 0.000 & 0.037 & 0.561 \\
\hline
\end{tabular}

$* * *$ significant at $0.01, * *$ significant at $0.05, *$ significant at 0.10 in $p$-values 
has zeros on the main diagonal, only the effects of the neighbouring region are taken into consideration. Neighbourhood levels were determined according to the amount of migration received by the regions. In other words, if one region receives a lot of immigration from the other region, the neighbouring degree of these two regions is high. So, $W$; spatial weight matrix, was created according to the migration-receiving of regions and row-standardized.

\section{Findings}

The estimation results are given in Table 3. It was decided by Hausman test to use a random-effect model except models 2 and 12. Based on the LM test, the spatial effect was detected in all models except 2 . In models 1,10 and 11 , the spatial effect emerged as a spatial lag. In all other models the spatial effect appeared as a spatial error. As mentioned before, due to the variables not included in the model, the spatial effect was observed in the error term in all these models.

In the models using both aggregated and disaggregated crime variables, the existence of the same relationship between crime and unemployment could not be confirmed. The adult unemployment rate is only significant in Model 1, Model 3 and Model 12, but in Model 12, it has a sign that does not match expectations. The dependent variables are theft in model 1 and 3 . The results imply that adult unemployment is correlated to theft. These results are similar to Altındağ (Altındağ, 2012), Saridakis and Spengler (Saridakis and Spengler, 2012) and Pazarlıoğlu and Turgutlu (Pazarlığlu and Turgutlu, 2007), but are not in accordance with Entrof and Spengler (Entrof and Spengler, 2000).

On the other hand, Model 1 is the only model where the youth unemployment rate is found to be statistically significant. Unlike expected, the sign is negative. This is explained by the traditional family structure in Turkey.

As unemployed young people are protected by their families, their tendency to crime is low. Similar results were reached when the youth unemployment rate was subdivided into gender and included in the analysis. Young unemployment rates defined by gender were found to be significant only in Model 2, where theft was a dependent variable, and in other models, coefficients that were insignificant and did not match expectations were obtained. While this result is in contradiction with the findings of many studies in the literature (e.g., Lombardo and Falcone, 2011; Özer and Topal, 2017; Fougere et al., 2009), Narayan and Smyth (Narayan and Smyth, 2004) found supportive results for our study. The results in Model 2 indicate a positive relationship between male youth unemployment and theft, whereas female youth unemployment and theft are inversely related. These results can be interpreted that women leave the labor market as the unemployment period 
increases. Crimes such as embezzlement and fraud in the definition of the crimes committed against the property require that the individual would first need to work in the relevant branch to commit that crime. As the participation of young people in the labor market is difficult, there is no relationship between these crimes.

In the estimation process, the youth unemployment rate was also subdivided according to education level and included in the model. While we expect that individuals are less prone to crime as their education level increases, the results supporting this hypothesis could not be obtained. While the results obtained from the model estimation are opposite to Altındağ (Altındağ, 2012), it is similar to Lauridsen et al. (Lauridsen et al., 2014). Entorf and Spengler (Entorf and Spengler, 2000) mentioned that these unexpected results are hard to explain in a conventional framework. Therefore, they stated that "employment increases illegal behaviour by exposing individuals to a wider network of delinquent peers" by referring to criminologists. So, we can say that the education system has no meaningful effect on individuals in Turkey committing a crime. It is fair to say that the education system in Turkey is not successful in keeping individuals away from crime.

The income variable (GDP) is statistically significant in all models estimated and has a positive coefficient. In this case, as the income level increases, crime rates increase and this result supports the results of Pazarlığlu and Turgutlu (Pazarlığlu and Turgutlu, 2007). This result, which seems to be opposed to the opinion expressed in the economic model of crime developed by Becker (Becker, 1968) and Ehrlich (Ehrlich, 1973), is also seen in many studies in the literature. Income can be used for illegal as well as legal reasons. If income is used to commit crimes (except rape and murder) in a society, it is not surprising that the rate of crime increases in that society (Entorf and Spengler, 2000).

The causes of violence crimes may be economic or non-economic reasons. It is stated in the literature that non-economic reasons are of greater importance in explaining violent crimes and the questions that sciences of psychology and sociology are trying to answer are discussed. Therefore, it is not surprising that statistically insignificant results are obtained in models 7,8 and 9, where violent crimes are treated as dependent variables. However, the fact that many unemployment variables have positive coefficients, even though it is statistically insignificant, shows that the results are consistent with expectations.

The most important finding is that the estimated results revealed a spatial structure of crime in Turkey. The spatial relationship was shown mostly in the spatial error model and the positive coefficient obtained showed the presence of positive migration effect. This coefficient shows that the migration-receiving increases the crime rates of the region. The main reasons for the positive correlation between immigration and regional crime rates are the variables not included in the model, so the spatial effect is determined in the error term. This result is similar to the results of Lauridsen et al. (Lauridsen et al., 2014). 


\section{Conclusions}

There has been an increase in crime rates and youth unemployment in Turkey in recent years. In this study, the relationship between youth unemployment and crime rates in Turkey was analysed by using spatial econometrics methods. The weight matrix created to define the structure of the spatial relationship consists of the migration amounts received by the regions. In order to examine the relationship between youth unemployment and crime rates, youth unemployment is divided into subgroups according to gender and their educational level. In the model, GDP and adult unemployment rates were used as control variables.

The results of the study do not show the expected relationship between youth unemployment and crime rates. This also applies to the sub-groups defined for youth unemployment. This can be explained by the social structure in Turkey. Young people are under the supervision of their families or close relatives for almost their entire lives. Newly graduated young unemployed people in Turkey get the full financial and spiritual support their families in all matters. Therefore, they are not exposed to the devastating effects of unemployment. This social structure, which is more conservative, increases solidarity under adverse economic circumstances and prevents individuals from tending to illegal behaviours.

The unemployment rate is insignificant defined by educational status shows that the inefficiency of the education system in Turkey. Both university and high school and vocational education levels are significantly lacking in terms of providing individuals with the skills required by today's labour market. This situation prevents individuals from finding a comfortable job. Therefore, the education system urgently needs to be reformed.

The results of the study have shown that crime has a spatial structure. The amount of migration received by the regions increases the crime rates in those regions. Migration causes many socio-economic variables in the region to be negatively affected, especially the social and demographic structure and labor market. In our study, since such variables were not represented in our models, spatial interaction could be explained by the spatial error model. This indicates that internal migration has significant impacts and emphasizes the revision and reconstruction of migration policies and all regional policies. The determination of socio-economic variables that have not been included in the study but may have led to the emergence of spatial interaction which should be the subject of future studies. 


\section{References}

[1] Adebayo, A.A. (2013) 'Youths' unemployment and crime in Nigeria: A Nexus and implications for national development', International Journal of Sociology and Anthropology, vol. 5(9), December, pp. 350-357.

[2] Ajaegbu, O.O. (2012) 'Rising Youth Unemployment and Violent Crime in Nigeria', American Journal of Social Issues and Humanities, vol. 2(5), September, pp. 315-321.

[3] Altındağ, D.T. (2012) 'Crime and unemployment: Evidence from Europe', International Review of Law and Economics, vol. 32, pp. 145-157.

[4] Anselin, L. (1988) 'Lagrange Multiplier Test Diagnostics For Spatial Dependence and Spatial Heterogeneity', Geographical Analysis, vol. 20, Issue 1, pp. 1-17.

[5] Anselin, L., Bera, A.K., Florax, R., Yoon, M.J. (1996) 'Simple diagnostic tests for spatial dependence', Regional Science and Urban Economics, vol. 26, Issue 1, pp. 77-104.

[6] Anselin L., Le Gallo J. and Jayet H. (2006) 'Spatial panel econometrics', in Matyas, L., Sevestre, P. (eds) The econometrics of panel data. Fundamentals and recent developments in theory and practice, 3rd ed Kluwer: Dordrecht.

[7] Baltagi, B.H., 2005. Econometric analysis of panel data, 3rd ed Chichester: Wiley.

[8] Becker, G.S. (1968) 'Crime and Punishment: An Economic Approach', Journal of Political Economy, vol. 76, No. 2, pp. 169-217.

[9] Bera, A. and Yoon, M. (1993) 'Specification testing with locally misspecified alternatives', Econometric Theory, vol. 9, Issue 4, pp. 649-658.

[10] Carmichael, F. and Ward, R. (2000) 'Youth unemployment and crime in the English regions and Wales', Applied Economics, vol. 32, pp. 559-571.

[11] Cerro, A.M. and Meloni, O. (2000) 'Determinants of the crime rate in Argentina during The '90s', Estudios de economia, vol. 27(2), December, pp. 297-311.

[12] Ehrlich, I. (1973) 'Participation in Illegitimate Activities: A Theoretical and Empirical Investigation', Journal of Political Economy, vol. 81, No. 3, pp. 521-565.

[13] Elhorst, J.P., 2003 'Specification and Estimation of Spatial Panel Data Models', International Regional Science Review, vol. 26, Issue 3, pp. 244-268.

[14] Entorf, H. and Spengler, H. (2000) 'Socioeconomic and demographic factors of crime in Germany: Evidence from panel data of German states', International Review of Law and Economics, vol. 20, Issue 1, pp. 75-106.

[15] Filiztekin, A. (2013) 'Türkiye' de suç ve emek piyasası İlişkisi', in Aşıc1, A., Hisarciklilar, M., Ilkkaracan, İ., Karakaş, D., and Kaya, T. (eds) Ümit Şenesen'e Armağan Paylaşımlar: Sayılarla Türkiye Ekonomisi, İstanbul: Lİteratür Press. 
[16] Fougere, D., Pouget, J. and Kramarz, F. (2009) 'Youth unemployment and crime in France', Journal of the European Economic Association, vol. 7(5), September, pp. 909-938

[17] Grönqvist, H. (2011) 'Youth Unemployment and Crime: New Lessons Exploring Longitudinal Register Data', Working Paper, Stockbolm University, Swedish Institute for Social Research, No. 7.

[18] Güvenç, B. (1996) 'Göç Olgusu ve Türk Toplumu', II. Ulusal Sosyoloji Kongresi: Toplum ve Göç, Mersin: Sosyoloji Derneği Yayınları.

[19] Hausman, J.A. (1978) 'Specification tests in econometrics'. Econometrica: Journal of the Econometric Society, vol. 46, 1251-1271.

[20] Jennings, W., Farrall, S. and Bevan, S. (2012) 'The economy, crime and time: An analysis of recorded property crime in England and Wales 1961-2006', International Journal of Law, Crime and Justice, vol. 40, pp. 192-210.

[21] Lauridsen, J.T., Zeren, F. and Ari A. (2014) 'Is crime in Turkey economically rational?', Discussion Papers on Business and Economics, University of Southern Denmark, No. 3, pp. 1-24.

[22] Lombardo, R. and Falcone, M. (2011) 'Crime and Economic Performance. A Cluster Analysis of Panel Data on Italy's Nuts 3 Regions', Working Paper, Universita Della Calabria, No.12, October.

[23] Narayan, P.K. and Smyth, R. (2004) 'Crime rates, male youth unemployment and real income in Australia: Evidence from Granger causality tests, Applied Economics, vol. 36, pp. 2079-2095.

[24] Özer, U. and Topal, M.H. (2017) 'Genç İşsizliği, Suç, Göç, Intihar ve Boşanma Düzeyleri ile ilişkili midir? Türkiye'den Ampirik bir Kanıt', Kirklareli University Journal of the Faculty of Economics and Administrative Science, vol. 6(5), December, pp. 50-63

[25] Pazarlıoğlu, M.V. and Turgutlu T. (2007) 'Gelir, İşsizlik ve Suç: Türkiye Üzerine Bir İnceleme', Finans Politik ve Ekonomik Yorumlar, vol. 44(513), pp. 63-70.

[26] Saridakis, G. and Spengler, H. (2012) 'Crime, deterrence and unemployment in Greece: A panel data approach', The Social Science Journal, vol. 49, Issue 2 , pp. 167-174.

[27] TESEV (Türkiye Ekonomik Ve Sosyal Etütler Vakfı), (2005) Türkiye'de Ülke İçerisinde Yerinden Edilme Sorunu: Tespitler ve Çözüm Önerileri, İstanbul: TESEV Yayınları.

[28] Tobler, W.R. (1979). 'Cellular geography', in Gale S., Olsson, G. (eds.), Philosophy in geography (pp. 379-386). Dordrecht: Springer.

[29] TURKSTAT [Online], Available: http://www.turkstat.gov.tr/Start.do [26 Apr 2019]. 


\section{Appendix}

\begin{tabular}{|l|}
\hline TR10 İstanbul \\
\hline TR21 Tekirdağ, Edirne, Kırklareli \\
\hline TR22 Balıkesir, Çanakkale \\
\hline TR31 İzmir \\
\hline TR32 Aydın, Denizli, Muğla \\
\hline TR33 Manisa, Afyon, Kütahya, Uşak \\
\hline TR41 Bursa, Eskişehir, Bilecik \\
\hline TR42 Kocaeli, Sakarya, Düzce, Bolu, Yalova \\
\hline TR51 Ankara \\
\hline TR52 Konya, Karaman \\
\hline TR61 Antalya, Isparta, Burdur \\
\hline TR62 Adana, Mersin \\
\hline TR63 Hatay, Kahramanmaraş, Osmaniye \\
\hline TR71 Kırıkkale, Aksaray, Niğde, Nevşehir \\
\hline TR72 Kayseri, Sivas, Yozgat \\
\hline TR81 Zonguldak, Karabük, Bartın \\
\hline TR82 Kastamonu, Çankırı, Sinop \\
\hline TR83 Samsun, Tokat, Çorum, Amasya \\
\hline TR90 Trabzon, Ordu, Giresun, Rize, Artvin, Gümüşhane \\
\hline TRA1 Erzurum, Erzincan, Bayburt \\
\hline TRA2 Ağrı, Kars, Iğdır, Ardahan \\
\hline TRB1 Malatya, Elazığ, Bingöl, Tunceli \\
\hline TRB2 Van, Mus,, Bitlis, Hakkari \\
\hline TRC1 Gaziantep, Adıyaman, Kilis \\
\hline TRC2 Şanlıurfa, Diyarbakır \\
\hline TRC3 Mardin, Batman, Şırnak, Siirt \\
\hline
\end{tabular}

